\title{
A Rare Complication in a Child with Sickle Cell Anemia: Clavicular Osteomyelitis
}

\author{
Orak Hücreli Anemili Bir Çocukta Nadir Bir Komplikasyon: \\ Klaviküler Osteomiyelit
}

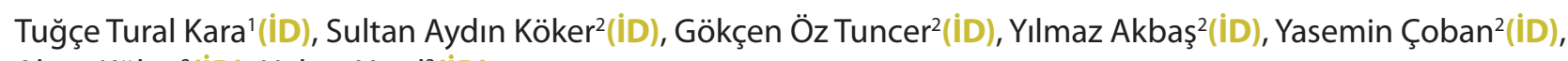

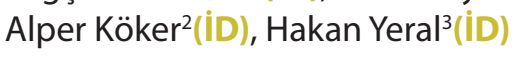 \\ 'Clinic of Pediatric Infectious Diseases, Hatay State Hospital, Hatay, Turkey \\ ${ }^{2}$ Clinic of Pediatrics, Hatay State Hospital, Hatay, Turkey \\ ${ }^{3}$ Clinic of Radiology, Hatay State Hospital, Hatay, Turkey
}

Cite this article as: Tural Kara T, Aydın Köker S, Öz Tuncer G, Akbaş Y, Çoban Y, Köker A, et al. A rare complication in a child with sickle cell anemia: Clavicular osteomyelitis. J Pediatr Inf 2020;14(1):e42-e45.

\section{Abstract}

Sickle cell anemia (SCA) is a hematologic disease that can cause severe infectious complications like osteomyelitis. Osteomyelitis commonly affects the long bones in children. However, atypical localizations have also been rarely reported. Herein, we aimed to present a pediatric patient with SCA, who was diagnosed as clavicular osteomyelitis. Our patient was admitted with painful and restricted movement of the right arm and shoulder. Physical examination revealed swelling, tenderness, erythema and localized temperature rise on the right clavicle. The patient received intravenous antibiotic treatment with a diagnosis of osteomyelitis. The patient, whose clinical and laboratory findings resolved, was discharged with oral treatment. On follow-up, there was no complication. Osteomyelitis is an infection that may cause serious complications in children with SCA. It is necessary to be kept in mind for differential diagnosis of the clinically suspected cases. It is possible to obtain full recovery with early diagnosis and appropriate duration and dose of antimicrobial treatment without surgery.

Keywords: Children, clavicle, sickle cell anemia, osteomyelitis

\section{Introduction}

Sickle cell anemia (SCA) is a hereditary hematologic disease frequently encountered in the world. As a result of dis-
Öz

Orak hücreli anemi (OHA) osteomiyelit gibi ciddi enfeksiyöz komplikasyonlara neden olabilen bir kan hastalığıdır. Çocuklarda osteomiyelit genellikle uzun kemikleri etkiler. Ancak nadiren de olsa atipik lokalizasyonlar bildirilmiştir. Burada, klaviküler osteomiyelit tanısı alan, OHA tanılı bir pediatrik hastayı sunmayı amaçladık. Hastamız sağ kol ve omuzda ağıı ve kısıtlı hareket şikayetiyle başvurdu. Fizik muayenesinde sağ klavikula üzerinde şişlik, hassasiyet, eritem ve lokalize ısı artışı tespit edildi. Hasta osteomiyelit tanısı ile intravenöz antibiyotik tedavisi aldı. Klinik ve laboratuvar bulguları gerileyen hasta oral tedavi ile taburcu edildi. İzlemde herhangi bir komplikasyon gelişmedi. Osteomiyelit, OHA tanılı çocuklarda ciddi komplikasyonlara neden olabilen bir enfeksiyondur. Klinik olarak şüpheli olguların ayırıcı tanısında hatırlanması gerekmektedir. Erken tanı, uygun süre ve dozda antimikrobiyal tedavi ile cerrahi olmadan tam iyileşme mümkündür.

Anahtar Kelimeler: Çocuk, klavikula, orak hücreli anemi, osteomiyelit

placement of glutamic acid with valine on the sixth position of the beta-globin chain, the atypical hemoglobin molecule called $\mathrm{Hb} \mathrm{S}$ is formed. Multiple organs are seriously affected since it is a multisystemic disease (1). Despite being an abnor- 
mality of red blood cells, the disease can cause chronic tissue ischemia and tissue infarction due to the blockage of vascular structures by sickle-shaped red blood cells (2). Patients in this group are under risk in terms of various infections, primarily encapsulated bacteria, due to functional asplenia and immature immune response (3).

Osteomyelitis is one of the osteoarticular infections presenting with bone involvement. This disease is one of the most commonly seen infectious complications in patients diagnosed with SCA. Microvascular disease and bone infarctions in particular establish a ground for the development of osteomyelitis (4). Osteomyelitis, on the other hand, leads to the misevaluation of the patients by often clinically mimicking vaso-occlusive crisis. Thus, diagnosis is delayed and difficulties and complications in treatment arise (5).

Osteomyelitis in children mostly occur in long bones. Nevertheless, osteomyelitis may rarely develop in the clavicle, ribs, spine, hand and foot bones. Clavicle involvement has been reported as $1-3 \%$ among all bones $(6,7)$. Clavicle osteomyelitis may develop due to hematogenous route, neighboring route or trauma. However, it mainly originates through hematogenous route in pediatric patients (8). This study aimed at presenting a case of clavicle osteomyelitis that developed in a pediatric patient followed for SCA and in whom complete recovery was achieved by early diagnosis and appropriate antimicrobial treatment without surgery.

\section{Case Report}

An 8-year-old male patient followed for SCA was admitted with pain in the right arm and shoulder, restriction in movement and fever that lasted for four days. Patient history showed that the patient's vaccinations were complete and that the patient received penicillin prophylaxis. Physical examination revealed a $5 \times 3 \mathrm{~cm}$ swelling, tenderness, erythema and increase in temperature on the clavicle. Mild adduction restriction was present on the right arm. An incision scar due to prior splenectomy was present on the abdomen. Laboratory results were as follows: hemoglobin: $9.4 \mathrm{~g} / \mathrm{dL}$, white blood cell: $30.300 / \mu \mathrm{L}$ (80\% neutrophil, $15 \%$ lymphocyte), platelet count: $396.000 / \mu \mathrm{L}, \mathrm{MCV}: 86.8 \mathrm{fL}, \mathrm{RDW}: 17.8 \%$, C-reactive protein (CRP): $113.2 \mathrm{mg} / \mathrm{L}$, sedimentation: $29 \mathrm{~mm} /$ hour. Direct graphy of the patient was assessed normal. On magnetic resonance imaging (MRI) of the clavicle taken following the graphy, increase in signal intensity consistent with bone marrow edema in the clavicle and intraosseous involvement consistent with osteomyelitis in soft tissue neighboring the periosteum were detected (Figures 1a, 1b). The patient was started on ceftriaxone and clindamycin with a preliminary diagnosis of osteomyelitis. The orthopedics department was consulted. The continuation of the present antibiotic treatment was recommended, and surgical intervention was not considered. There was no pathogen from the blood and urine cultures taken prior to the antibiotics. On the sixth day of treatment,

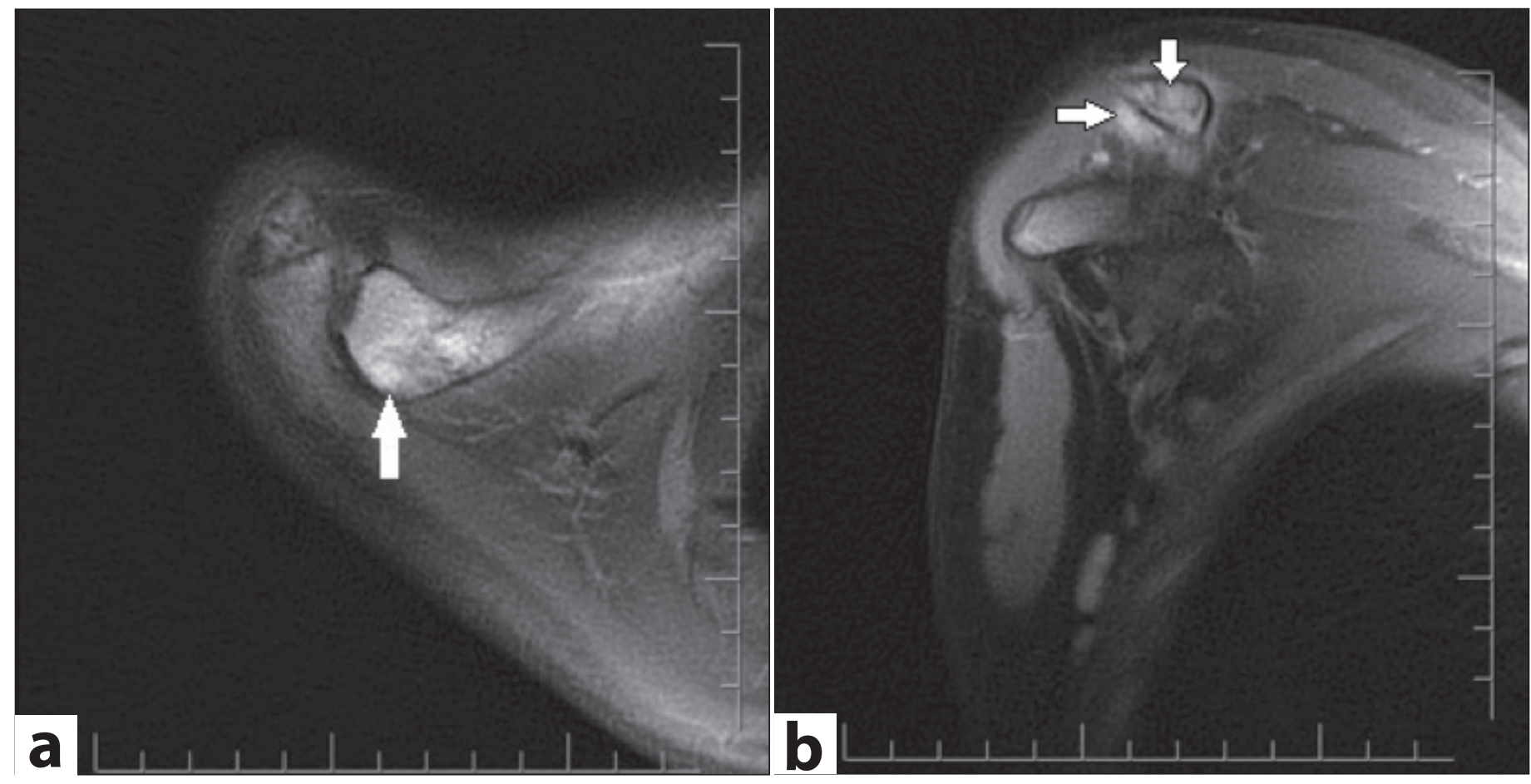

Figure 1. a. Increase in signal intensity consistent with bone marrow edema in the clavicle on axiel STIR MRI (white arrow). b. Following the injection of intravenous contrast matter, intraosseous involvement consistent with osteomyelitis in soft tissue neighboring the periosteum on coronal oblique T1 fat suppressed sequence is seen (white arrows). 
the fever and acute phase reactants of the patient regressed and clinical findings moderated. Total treatment of the patient was completed in four weeks with intravenous therapy. The patient was discharged following the prescription of a twoweek oral amoxicillin-clavulanate. No complication was seen during the 6-month follow up following discharge.

\section{Discussion}

SCA is a hematologic disease that can cause severe complications. Despite prophylactic penicillin, vaccination and fast transportation to healthcare facilities, it can still lead to life-threatening conditions, some of which include vaso-occlusive crisis, acute chest syndrome, priapism, and osteomyelitis. It is seen in pediatric patients with diagnosis of SCA that osteomyelitis mainly develops in long bones. In spite of wide SCA population, limited number of cases has been reported in the literature regarding clavicle osteomyelitis (9).

Clavicle osteomyelitis is rare in children. Therefore, there may be delays in diagnosis and treatment. In a study reviewing 294 cases of clavicle osteomyelitis, blood culture positivity has been found as $81 \%$. Staphylococcus aureus (44.70\%), Mycobacterium tuberculosis (21.18\%) and Pseudomonas aeruginosa $(7.06 \%)$ have been reported as the most frequently detected agents (10). The most common osteomyelitis agent is Salmonella spp. in SCA.

Immunosuppression, surgical procedures, subclavian catheterization, and trauma are primary risk factors (8). The anatomic structure of the clavicle gives rise to difficulties in treatment. Pathologic fractures and deterioration in blood flow due to any reason can pave the way for the osteolysis of the medial segment. Hence, osteomyelitis of the clavicle, like other flat bones, can be treated more problematically when compared to long bones (6).

The rarity of clavicle osteomyelitis and its clinical and/or radiologic similarity with diseases like trauma, fracture, cellulitis, soft tissue abscess, ischemic necrosis, tumor, chronic recurrent multifocal osteomyelitis that should be kept in mind in differential diagnosis lead to difficulties in diagnosis $(6,8)$. Patients frequently present with symptoms such as acute onset of fever, pain, swelling on the shoulder, restriction in movement, rash, and crepitus. Our patient presented with acute onset of fever, swelling on the shoulder, tenderness and increase in temperature.

No finding can be detected until the first 14 days on direct radiography. Ultrasonography can be helpful for the diagnosis by aiding in detecting soft tissue swelling which is an early finding of acute osteomyelitis. However, normal ultrasonographic investigation do not exclude osteomyelitis. Computed tomography is more sensitive in early diagnosis. Nonetheless, the gold standard in the diagnosis of osteomyelitis and its complications is MRI. It serves an advantage especially in the evaluation of the soft tissue (11). Though direct graphy did not determine osteomyelitis in our patient, MRI confirmed the diagnosis.

A study examining non-traumatic lesions in the clavicle supports that if patients with osteomyelitis are treated with appropriate antibiotic therapy, the patients can recover with the re-shaping of the clavicle. In addition, this study has suggested that lesion biopsy does not serve as an additional aid in the diagnosis of osteomyelitis made with clinical symptoms and findings. It has been emphasized that typical clinical findings like increase in temperature, swelling and tenderness in the infection site, radiological findings like loss of trabecular structure, localized osteopenia and/or sclerosis and periosteum reaction and laboratory findings like elevated CRP and/or sedimentation are sufficient for establishing the diagnosis of osteomyelitis. Advanced radiologic investigation and biopsy have been recommended in patients whose clinical findings do not ameliorate with appropriate antimicrobial treatment for 1-2 weeks (12). Our patient also received antibiotic treatment empirically. Moreover, biopsy was not found necessary since the patient benefitted from this treatment and MRI results supported our osteomyelitis diagnosis.

The purpose in osteomyelitis treatment is to suppress the infection and prevent the development of complications. Therefore, first-line treatment should be carried out with appropriate antimicrobial agents. These antimicrobials used in empiric treatment should contain antistaphylococcal penicillin that covers the most common agent of osteomyelitis S. aureus, clindamycin, first generation cephalosporin and clindamycin or vancomycin in regions where methicillin-resistant S. aureus (MRSA) is seen $>10 \%$ (6). Duration of standard antibiotic treatment for osteomyelitis is 4-6 weeks. Treatment started intravenously continues with oral antimicrobial agents. Decrease in CRP value can be a guide in shifting to oral treatment. Furthermore, the penetration of the oral agent into the bone tissue must be effective (13). Following a 4-week intravenous ceftriaxone and clindamycin treatment, our patient recovered completely with a two-week oral amoxicillin.

In the literature, the association of SCA and clavicle osteomyelitis has been reported as a case report. In this case, a 10-year-old male patient presented with fever and chest pain. Similar to our patient, acute phase reactants of this case increased and while direct graphy findings were normal at the onset of the disease, MR imaging detected the development of osteomyelitis in the sternum and clavicle. The patient recovered without sequel with intravenous treatment (9).

\section{Conclusion}

Osteomyelitis is a commonly encountered infectious complication in patients with SCA diagnosis. It should be kept in 
mind that atypical bone involvement can be seen in clinically suspected cases. It is possible to have complete recovery without sequel with early diagnosis and antimicrobial treatment at an appropriate dosage and duration.

Informed Consent: Written consent was obtained from the parents of the patient.

Peer-review: Externally peer-reviewed.

Author Contributions: Concept - TTK, SAK, GÖT; Design - TTK, YA, YÇ; Supervision - TTK, AK, HY; Materials - TTK, SAK, GÖT, YA; Data Collection and/or Processing - TTK, YÇ, AK; Analysis and/or Interpretation - TTK, SAK; Literature Review - TTK, GÖT, HY; Writing TTK; Critical Review - TTK, YA, AK.

Conflict of Interest: No conflict of interest was declared by the authors.

Financial Disclosure: The authors declared that this study has received no financial support.

\section{References}

1. daSilva Junior GB, DaherEdeF, da RochaFA. Osteoarticularinvolvement in sickle cell disease. Rev Bras Hematol Hemoter 2012;3:156-64.

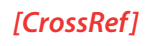

2. Inusa $B P$, Oyewo $A$, Brokke $F$, Santhikumaran $G$, Jogeesvaran $K H$. Dilemma in differentiating between acute osteomyelitis and bone infarction in children with sickle cell disease: the role of ultrasound.

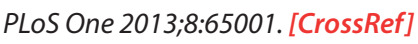

3. Bennet GC, Bennet SJ. Infection of bone and joint. Surgery 2006;24:2114. [CrossRef]
4. Ganguly A, Boswell W, Aniq H. Musculoskeletal manifestations of sickle cell anemia: a pictorial review. Anemia 2011;2011:794283. "[C Cross Ref $]_{1}$

5. Ngwube A, Jackson S, Dixon T, Spampinato M, Losek JD. Disseminated Salmonella osetomyelitis in a 2-year-old with sickle cell disease. Clin Pediatr (Phila) 2012;51:594-601. '[Cross Ref] ",

6. Chrysochoou EA, Antachopoulos C, Badekas K, Roilides E. A rare case of clavicle osteomyelitis in a child and literature review. Case Rep Pediatr

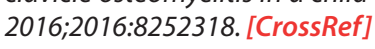

7. Akakpo-Numado GK, Gnassingbé K, Abalo A, Boume MA, Sakiye KA, Tekou H. Locations of osteomyelitis in children with sickle-cell disease at Tokoin teaching hospital (Togo). Pediatr Surg Int 2009;25:723-6. [CrossRef]"

8. Ghate S, Thabet AM, Gosey GM, Southern EP, Begue RE, King AG. Primary osteomyelitis of the clavicle in children. Orthopedics 2016;39:760-3. [CrossRef $]_{1}$

9. Al-Fifi SH, Al-Qahtani SM, Al-Binali AM, Annobil SH. An unusual complication of sternal and clavicle osteomyelitis in a child with sickle cell disease. Saudi Med J 2002;23:589-90. [CrossRef]

10. Hu WR, Yao ZL, Yu B, Jiang N. Clinical characteristics and treatment of clavicular osteomyelitis: a systematic review with pooled analysis of 294 reported cases. J Shoulder Elbow Surg 2019;28:1411-21. [C CrosśRef́

11. Suranigi $S M$, Joshi $M$, Deniese $P N$, Rangasamy $K$, Najimudeen $S$, Gnanadoss JJ. Chronic osteomyelitis of clavicle in a neonate: report of morbid complication of adjoining MRSA abscess. Case Rep Pediatr

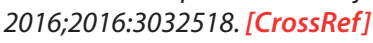

12. Clement ND, Nicol G, Porter DE. Nontraumatic lesions of the clavicle in a paediatric population: incidence and management. Int Sch Res Notices 2014;2014:261952. [C CrossRéf $]_{1}$

13. Peltola H, Paakkönen M. Acute osteomyelitis in children. N Engl J Med 2014;370:352-60. "[C CrossRef ]" 